\title{
EFL Students' Interpretations of e-Learning during COVID-19 using GETAMEL: Indonesian Higher Education Context
}

\section{Dedy Yulianto, ${ }^{1 *}$ Endang Setyaningsih, ${ }^{2}$ Sumardi Sumardi ${ }^{3}$}

English Education Department, Faculty of Teacher Training and Education, Universitas Sebelas Maret, Jl. Ir. Sutami No.36 A Surakarta 57126, Indonesia

\author{
*) Corresponding Author \\ Email: ddy45425@gmail.com
}

DOI: 10.18326/rgt.v14i2.203-224

\section{Submission Track:}

Received: 05-06-2021

Final Revision: 01-12-2021

Available Online: 05-12-2021

Copyright @ 2021 Author(s)

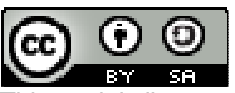

This work is licensed under a Creative Commons Attribution-ShareAlike 4.0 International License.

\begin{abstract}
While the use of e-learning has been around for decades, the global pandemic increased the number of investigations on e-learning exponentially. Earlier studies have given useful insights into the benefits/ impacts of e-learning. However, students' acceptance of technology within the context of emergency EFL remote teaching is still under-researched. A qualitative study framed within the General Extended Technology Acceptance Model for E-Learning (GETAMEL) aims to shed light on students' acceptance of technology during pandemics based on their perceived experience. It reports the challenges, opportunities of e-learning, and projections on future use based on the current experience. To collect the data, a questionnaire consisting of open and closed questions was distributed to 89 participants. In-depth interviews were conducted with focal respondents after gaining their consent. The data were then analyzed using the interactive model of data analysis. This study reveals that regardless of the negative experiences and challenges in the use of technology in e-learning, the students held positive perspectives and saw opportunities to use technology during the COVID-19 pandemic. They projected their future practice using the technology. These indicate that the students well accept the use of technology in the elearning context. The study concluded that using e-learning during a pandemic is the ideal way to continue learning. However, given the challenges that students face, some changes in the implementation of distance learning are still needed. Additional studies should address GETAMEL on EFL teachers in an Indonesian school, so we know about the acceptance of elearning by in-service teachers.
\end{abstract}

Keywords: COVID-19; EFL students; e-learning; GETAMEL; higher education 


\section{INTRODUCTION}

Responding to the increasing number of COVID-19 cases which turn into a global pandemic, governments across the globe have issued special regulations for educational institutions. Schools are closed and the teaching-learning process should run from homes. The schools' closure has led to the massive use of online technologies to boost the practice of distance learning (Dhawan, 2020).

In Indonesia, the Minister of Education and Culture has directed all education units to run online learning beginning March 24, 2020 (Mendikbud, 2020). Online learning is viewed as a way out to maintain the learning process amidst the pandemic. The switch to online learning entails the implementation of internet-based learning in which the activities are conducted through the Internet. This internet-based teaching and learning is called e-learning (Schworm \& Gruber, 2012).

E-learning provides many opportunities for students and teachers to conduct distance learning while improving student-centered learning (Kumar Basak et al., 2018). Many pieces of evidence have been found in studies on the benefits of e-learning, such as e-learning offering flexibility to be utilized anywhere and at any time (Shah, 2016); a platform for students/ instructors to develop autonomy in their study (Joshi et al., 2020); and better media quality used to distribute materials for the students (Sarker et al., 2019).

Aside from the opportunities it provides, e-learning is closely linked to the challenges that arise. The researcher had been investigating the difficulties that students encountered using e-learning for a long time before the pandemic spread across the world (Fincham, 2016). The study's findings emphasize that distance learning cannot replicate the student experiences acquired in face-toface classes, even when students communicate via e-mail, Skype, virtual learning environments, or teleconferencing. Other results found that the digital divide, primary learning goal, and teacher-student interaction are the most challenging that students face (El Refae et al., 2021). Furthermore, they mentioned that students had problems when participating in distance learning, such as a poor internet connection, poor images and sound, a lack of realistic applications, classroom management, and a communication gap between instructors and students. 
The use of e-learning during pandemics has been implemented for years. During COVID-19, some studies regarding the effect of distance learning for students were reported in many kinds of research (Mishra et al., 2020; Rizun \& Strzelecki, 2020). Nevertheless, the studies regarding students' acceptance of elearning as a response to a change in learning are limited in the context of EFL students in Indonesia. In 2016, the well-known Technology Acceptance Model (TAM) has been developed into a General Extended Technology Acceptance Model for E-Learning (GETAMEL) (Abdullah \& Ward, 2016). GETAMEL was built to measure the students' acceptance of technology especially the use of elearning. It consists of eight constructs: perceived ease of use, perceived usefulness, experience, subjective norms, enjoyment, computer self-efficacy, and anxiety.

First, perceived ease of use can be described as how people think the work can be done with less effort using technology (Davis, 1989). It means that people want to use technology because they believe it can help them easily complete their tasks. Second, perceived usefulness is the degree to which a person feels his work success will be improved using a certain technology (Davis, 1989). It means that people believe that technology can improve their performance to finish their jobs. Third, intention to use is the tendency to use a certain technology. It is defined as a tendency to use technology that can be seen by their attention and enthusiasm to use technology and their ability to inspire other users (Davis, 1989). Fourth, the experience is related to the amount and type of computer knowledge a person has gained over time (Smith et al., 1999). It means that a person with greater computer skills and experiences has more optimistic feelings towards the use of every online/ distance learning tool.

Fifth, subjective norm refers to the view of the individual that other people who are relevant to him believe that a certain action should or should not be done (Venkatesh et al., 2003). In this case, the subjective norm has to do with how the views of colleagues, teachers, and education policy affect the tendency of students to use e-learning. This suggests that students would use e-learning if other people they consider relevant/important suggested doing so. Sixth, enjoyment is understood as the degree to which implementing any system or 
technology is considered enjoyable (Ryan \& Deci, 2000). Many studies show that the enjoyment of using any device influences the students' perceived ease of use and perceived usefulness.

Seventh, anxiety is defined as an appeal to worried or emotional reactions when a person wanted to do something (Venkatesh et al., 2003). In the context of computer anxiety, it means that someone's anxiety when he wants to do a job using a computer. Last, self-efficiency refers to an independent judgment of his or her own ability to perform a particular task (Bandura, 1982). Therefore, computer self-efficacy can be described as a user's belief that he or she can perform a certain task using a computer. Findings also suggest that students who have higher e-learning, self-efficacy are more likely to use e-learning and computer-supported education.

Furthermore, this study is aimed to explore students' acceptance of elearning, the challenges, and opportunities during COVID-19, and their projection of future use by adapting the GETAMEL as a guiding instrument. The research questions are formulated as follows: (1) How are the EFL students' acceptance and projection of future use of e-learning based on the current experiences during COVID-19? (2) What are the perceived challenges and positive opportunities EFL students feel in shifting into e-learning during COVID-19?

\section{RESEARCH METHODS}

This study used the qualitative case study to address the in-depth research questions and representing their reality (Yin, 2018). A survey was conducted with an open-ended questionnaire and online semi-structured interviews. The questionnaire consisted of 33 questions. It adapted from GETAMEL and added some questions regarding research needs and 16 semi-structured interviews, it was intended to find out the challenges and opportunities that e-learning serves during a COVID-19 pandemic and their acceptance of e-learning. The target of the online survey was EFL students in Indonesia. The semi-structured interview also served to triangulate the data.

This research included $89 \mathrm{EFL}$ students. Convenience sampling was used to recruit participants. According to Edgar \& Manz (2017) convenience 
sampling is a technique for taking samples that are easily reachable near a location or internet service. Given the current COVID-19 pandemic situation, it was decided to choose participants who were easiest to locate or contact.

\section{Data Collection}

Interview and questionnaire instruments were designed to gather information related to the research questions. The questionnaire was adapted from GETAMEL to measure technology acceptance. Furthermore, the interview was conducted to get the data related to the challenges and opportunities that the COVID-19 pandemic offered. The interview was conducted for around 15 to 30 minutes for each participant. It was conducted using Google Meet and WhatsApp because the interview cannot be conducted directly face-to-face during the pandemic. The interview was carried out in Bahasa Indonesia to get a better understanding of the information given by the interviewee.

\section{Data Analysis}

The collected data were then analyzed by following steps proposed by Miles, Huberman, \& Saldana (2014). The analysis of the data offered different phases including (1) data condensation; (2) data displays; and (3) drawing conclusion \& verification. First, data condensation was carried out by selecting and simplifying relevant data through coding. Second, data display was carried out by arranging and tabulating codes that enable conclusions. Third, drawing conclusions was carried out by interpreting the data through data condensation, data display, and also data collection to prevent data loss.

\section{RESULTS AND DISCUSSION}

This section conveys four main concepts concerning the EFL students' acceptance of e-learning, the difficulties, the constructive opportunities, and the projection to use e-learning for future practices. For each of the four concepts, the most representative excerpts from the participants' responses are chosen.

\section{The EFL Students' Acceptance of e-Learning during a Pandemic}

After more than a year of full-time online study through e-learning during the pandemic, the students used a variety of e-learning platforms to perform 
activities. Full online learning has influenced the students, as shown by how they viewed e-learning. This research revealed that the students' acceptance of using e-learning is well accepted. In line with the study conducted by Ismaili (2021), the students were pleased with their e-learning experience. The research also found that the use of e-learning during the pandemic are classified as positive and negative experiences, as follows:

\section{Positive experience}

The students feel a positive experience towards the use of e-learning which they got from benefits that present for students. This part will be divided into four categories: usefulness, ease of use, student enjoyment, and computer self-efficacy.

\section{Usefulness}

In the COVID-19 pandemic, most students decide that e-learning will increase their learning efficiency. In line with the previous study, Kratochvil (2014) found that e-learning could increase the efficiency of students learning. In addition, Chopra et al. (2019) found that the use of e-learning may also help students advance in their careers and become more employable.

Subsequently, in this study, EFL students perceived the usefulness of using e-learning in terms of time savings, learning performance, and effectiveness. The table below depicts the results of computations of questionnaire data and summarized interview data concerning participants' attitudes regarding elearning during the COVID-19 pandemic.

\section{Table 1}

Usefulness Using e-Learning

\begin{tabular}{lcc}
\hline Usefulness & Respondents & Percentage \\
\hline Time-saving & 48 & $54.5 \%$ \\
Learning performance & 42 & $47.2 \%$ \\
Learning effectiveness & 38 & $42.7 \%$ \\
\hline
\end{tabular}


Table 1 shows that by using e-learning during COVID-19, the students agree that e-learning can complete the task quickly thus saving most of their time; improve their learning performance and effectiveness. It can be concluded that almost half of them experience the usefulness of using e-learning during the pandemic. Furthermore, the results of the interview consistently confirm and validate the questionnaire results. For instance, the students can effectively use the time to finish their group project without having to meet in one place.

“... when there is a group assignment, we don't need to wait to meet each other but we can have discussions via google meet or zoom" (YS, personal communication, 2021)

Most students accept that e-learning can improve their academic performance. For instance, students do not have to take notes on paper, they can exchange materials via Google Drive, and they can study from anywhere and at any time.

“... I think it is very good because I do not need to use paper and it does not get scattered ..." (WGT, personal communication, 2021)

Based on the data obtained, EFL students believe that using e-learning during the COVID-19 can increase their success in finishing most of the studying activities. Making them more helpful during the pandemic so that they can learn almost as normal.

\section{Ease of use}

Moreno et al. (2017) said that to be effective to use an e-learning system, the students' experience is associated with usefulness and ease of use. In this study, the same conclusion is reached. Students perceived the ease of use of elearning after perceiving its usefulness. EFL students believe that using elearning in a COVID-19 pandemic makes learning distribution simpler. The students have easy access to the availability and accessibility of the e-learning platform (Ismaili, 2021). The following table, which has been condensed but made representative, presents some of the most important points of the data collected. 


\section{Table 2}

Ease of Use

\begin{tabular}{lcc}
\hline Ease of use & Respondents & Percentage \\
\hline Easy to use & 49 & $55.1 \%$ \\
Easy of physical effort & 51 & $57.3 \%$ \\
Easy of mental effort & 42 & $47.2 \%$ \\
\hline
\end{tabular}

The table shows that e-learning is easy for the students to use in learning activities; they agree that using e-learning is free of physical and mental effort. The easiness of using e-learning is also supported by the result of the interview, which confirms the data. For example, students have no problem using Zoom or Google Meet to conduct learning.

"My experience with e-learning includes using many websites such as Spada, ... there are also other websites such as Schoology, whose use is not much different ..." (MA, personal communication, 2021)

It can be interpreted that the e-learning system is very easy to use regardless of the number of e-learning available out there. Most of the elearnings have the same features to allow students to easily use them. In addition, an e-learning system makes students free from physical and mental burdens that can occur during the pandemic. For instance: the students can get proper teaching from their own home. Thus make them physically free from going to the classroom.

"I feel comfortable using e-learning at home during this lecture because, with e-learning, students don't need to go to campus to study in a pandemic like this" (LAP, personal communication, 2021)

Moreover, students do not need to think hard if they have to use the new e-learning system. It means that the students are also mentally free of effort in understanding the use of new e-learning.

"My experience in using e-learning is the Schoology platform and the Spada which in my opinion is very easy to use and not too complicated" (DSS, personal communication, 2021) 
From the data above, it can be concluded that EFL students believe using e-learning during the COVID-19 pandemic makes learning distribution simpler and allows the students to operate the e-learning as desired.

\section{Students' enjoyment}

The data gathered from participants reveal that students enjoy using elearning for educational purposes. The study claims that enjoyment becomes an important aspect in supporting the acceptance of using e-learning. As reported by Ashrafi et al. (2020) the intention to continue to use a system is affected by the enjoyment and subjective norm.

In contrast with the previous finding, this study finds that enjoyment affects their decision to use e-learning, but subjective norm has only a small even less effect on EFL students' acceptance during the COVID-19 pandemic.

\section{Table 3}

Enjoyment

\begin{tabular}{lcc}
\hline Enjoyment & Respondents & Percentage \\
\hline Pleasure & 35 & $39.3 \%$ \\
Competence & 41 & $46.1 \%$ \\
Engagement & 33 & $37.1 \%$ \\
\hline
\end{tabular}

Table 3 shows that the students find it fun using e-learning; they are competent in using e-learning, and they like to interact with e-learning. The result from the interview also validates the data. It shows that the students' enjoyment stems from the ease with which they can access the materials. For example, students can access the materials at any time and from any location.

"My experience while using e-learning during this pandemic, e-learning can help to keep learning and can be used anywhere" (ARM, personal communication, 2021)

In addition, some students state that they like using e-learning because it makes material delivery more interesting, convenient, easy, and they do not have to meet in person, which is particularly important during this pandemic. In terms of engagement, the students agree that there is a decrease in interaction between students and lecturers. The same result was also conveyed by Luaran 
et al. (2014), who stated that using e-learning gradually decreases contact between students and teachers compared to face-to-face classes. However, some students feel comfortable because they are not required to communicate or meet with many people or go outside to study.

"I feel comfortable using e-learning at home during this lecture because, with e-learning, students don't need to go to campus to study in a pandemic like this" (LAPu, personal communication, 2021)

In conclusion, EFL students show enjoyment when using e-learning to study. The enjoyment is also related to their perception of usefulness and ease of use (Almekhlafy, 2020).

"In a pandemic like this, I think it is necessary to implement e-learning because it is arguably the most effective step so that the teaching and learning process can continue" (IF, personal communication, 2021)

It is conclusive that the technology of e-learning is preferable to use in the time of COVID-19 where every student should learn at home. Aside from avoiding face-to-face meetings, e-learning allows for continuous learning.

\section{Computer self-efficacy}

Chung et al. (2015) stated that computer self-efficacy can influence the students' intention to use a certain system. Supported by Yeou (2016) who discovered that computer self-efficacy is important in accounting for attitude and technology utilization. The same result is found in this study during the pandemic, students have a high level of self-efficacy. Some students have been exposed to e-learning since they were in junior or senior high school.

"Because they have used the platform before the pandemic (Schoology, Spada, Meet, Zoom, Google class) so they are not surprised and panicked when receiving instructions during distance learning" (IK, personal communication, 2021)

Table 4

Computer Self-Efficacy

\begin{tabular}{lcc}
\hline Computer Self-Efficacy & Respondent & Percentage \\
\hline Prior knowledge & 43 & $48.3 \%$ \\
Autonomous learner & 46 & $51.7 \%$ \\
Support & 33 & $37.1 \%$ \\
\hline
\end{tabular}


Table 4 shows that EFL students have already experience and knowledge about e-learning; they learn autonomously and can operate e-learning by following the manual books. It means that the students believed in their ability to perform the task by using e-learning with ease.

As previously stated, their confidence comes from having prior experience with computers and knowledge about software and technological issues. Prior experience is one of the factors that greatly influence the use of e-learning later by students. According to Almekhlafy (2020), students who have no prior experience with online learning have a significant impact on the attitudes of students who use online learning.

"I am very experienced in the field of computers, especially basic computer software and technical problems, and I am still interested in exploring other methods of learning through e-learning" (AAR, personal communication, 2021)

Despite their first experience using e-learning, students remain confident in their abilities. They use e-learning by following the instructions in manuals or help from peers. The students will seek alternative solutions if anything is not known.

"I can use an e-learning by looking at the user manual or if I feel confused, I can ask a friend who already understands using e-learning" (MCAKW, personal communication, 2021)

"Perhaps as a result of the internet's assistance, I have developed the habit of automatically searching for how to use e-learning, if I do not understand" (NDE, personal communication, 2021)

It can be concluded that EFL students are quite confident with their ability to operate e-learning during the COVID-19 pandemic. At first, students are confused about using e-learning, but they become accustomed to it and believe it is more effective as time passes. Further, it is a need for the students to have a high computer self-efficacy and is important to boost their confidence to complete the study.

\section{Negative Experience}

The issue of understanding the material is the negative experience that students have while using e-learning during a pandemic. The same issue was 
reported by Patricia Aguilera-Hermida (2020), students are having trouble comprehending the entire online learning given.

"There are many things that we usually understand easily, such as in face-toface classes, I am worried that if there is the knowledge that does not arrive due to the interference, even though the lecturer/teacher has prepared the data by presenting via PowerPoint, doc, pdf and so on" (FI, personal communication, 2021)

Understanding learning content becomes a concern among students. It is also supported by the result of the interview from the participants who claimed that they are afraid that they cannot absorb the material properly. This is feared because it can potentially reduce the academic achievement of students.

Table 5

The Factors that Affect Students' Understanding

\begin{tabular}{lcc}
\hline The factor affects students' understanding & Respondents & Percentage \\
\hline Internet issues & 42 & $46.2 \%$ \\
Quota internet & 12 & $13.2 \%$ \\
Health issues & 9 & $9.9 \%$ \\
\hline
\end{tabular}

This study finds three factors representing a concern for students. The table shows that the difficulty in understanding the material is caused by three factors, namely Internet issues, Internet quota, and health issues.

In some areas, Internet connection is difficult to predict (sometimes stable, sometimes unstable), which contributed to the issue. Students, especially those who live in rural areas, are affected by this issue (Lai \& Widmar, 2021). They complain about the unreliable network during learning, which caused them to miss content, experience delays in submitting assignments, or fail in delivering assignments.

“... sometimes you experience problems on the unstable internet signal, so the learning process is interrupted" (SNB, personal communication, 2021)

Conventional teaching has become all online, causing Internet quotas to run out faster. The same thing was found by Fawaz et al. (2021), students felt the difficulties of using technology during the COVID-19 pandemic, one of which was the Internet quota that is not sufficient for their needs. This is one of the 
concerns that students have, as they spend two to three times as much on the Internet.

"Internet problems such as running out of quota or network errors, as well as problematic gadgets" (IK, personal communication, 2021)

On the other hand, the students are concerned about their well-being (Grubic et al., 2020). These issues had also been addressed by Kratochvil (2014). Students are often concerned about their health because all classes are delivered entirely online, requiring them to spend time in front of a laptop. Vision problems and stress are among the health issues. For example, many students complain that their eyes hurt from staring at the laptop screen for too long.

"Anxiety is on eye health, because we have to stare at the screen of a smartphone or laptop for hours, plus the number of tasks given will increase the time to look at the smartphone or laptop screen" (LN, personal communication, 2021)

In addition, staring at a laptop screen for an extended period induces stress and dizziness. Moreover, not socializing with other people also causes stress and mental fatigue for some students.

"The stress of not doing socializing with many people and the long screen-time made me very tired and greatly affected my mental condition" (DJ, personal communication, 2021)

It can be concluded the negative experience that the students mostly feel is related to Internet use and health issues. Because they come from different regions, students have different internet speeds depending on where they live. Coupled with the use of devices for the long term also affects the health of students. Mental and physical health issues are important factors for teachers and institutions to consider.

\section{The Challenges Faced During the Pandemic}

Yan et al. (2021) confirmed that the sudden transition from face-to-face learning to fully online learning will create its own set of problems for the students. The data collected from a questionnaire containing a list of problems that students may encounter can be extracted from the top three problems that they often meet. 
D. Yulianto, E. Setyaningsih, S. Sumardi

Table 6

The Challenges Faced by the Students

\begin{tabular}{lcc}
\hline The challenges & Respondents & Percentage \\
\hline Much Homework & 64 & $73.6 \%$ \\
Distraction from humans, pets, or others & 48 & $55.2 \%$ \\
Socio-economic & 41 & $47.1 \%$ \\
\hline
\end{tabular}

The table states that the students are given more homework than usual; have a problem with their family members, and have an economic problem to purchase qualified devices. It means that during COVID-19 mostly the EFL students feel burdened by those problems. It is confirmed from the students' interview.

The first issue, many students accept that the amount of homework assigned during the pandemic is significantly higher than average (Jan, 2020). During the first pandemic, nearly every lecturer assigned homework to students with little time to complete.

"The anxiety that I often feel, namely when given assignments and the deadlines given is very short" (LP, personal communication, 2021)

The second concern is the distraction at home. The students complain that their family is making noise during the learning activity (Iivari et al., 2020), which is interfering with their concentration. This makes it difficult for them to concentrate on their studies.

"I am also sometimes annoyed by family members making loud noises" (PKD, personal communication, 2021)

Another issue is that certain students do not have a proper device for online learning. It is normally caused by their family's financial situation.

"The cellphone that I have is also not very supportive for online learning, so the results are not optimal" (LD, personal communication, 2021)

The financial issue was associated with the number of quotas that they can purchase based on their economic background (Pokhrel \& Chhetri, 2021). They can only afford to purchase a small quota to participate in online learning. 


\section{Opportunities Driven by the Pandemic}

Given the number of challenges, we must search out opportunities that will enable us to perform to the best of our abilities. For example, the shift from face-to-face to entirely online learning has made lecturers and students more conscious of the value of e-learning in the classroom.

"... there are also platforms such as using Kahoot, Quizzes, English Score, etc. And I think all of them are quite interesting and make me know about other elearning applications" (LRR, personal communication, 2021)

The data obtained from the questionnaire, which includes a list of opportunities, is provided to students and conclusions can be drawn from the top three. This segment will look for the opportunities that students see by using e-learning during a pandemic.

\section{Table 7}

Potentials Provided by the Pandemic

\begin{tabular}{lcc}
\hline The potentials & Respondents & Percentage \\
\hline $\begin{array}{l}\text { Introduced to various types of educational } \\
\text { technology }\end{array}$ & 73 & $83.9 \%$ \\
$\begin{array}{l}\text { More independently searching for learning } \\
\text { resources }\end{array}$ & 71 & $81.1 \%$ \\
Technological savvy & 67 & $77 \%$ \\
\hline
\end{tabular}

EFL students state the opportunities of fully online learnings have introduced them to many kinds of e-learning; they become better at finding references on the internet, and more familiar with e-learning technology. Those are the three things that the EFL students feel during the COVID-19 pandemic.

First is the increased knowledge of e-learning during the COVID-19 pandemic; by gaining hands-on experience with a variety of e-learning applications, their understanding of e-learning greatly improves.

"All courses use the E-learning system today. The platforms used have different apps, so I can understand a lot of the applications involved and I believe they will be very useful in the future" (MF, personal communication, 2021) 
Second, the students become independent learners. The pandemic has given more time to search for additional learning materials from the internet. It provides excellent opportunities for students to develop their methods of searching for materials.

"I learned how various platforms work that I didn't understand before and encouraged me to explore further via the internet if I was still confused about how an e-learning application works" (PKD, personal communication, 2021)

Third, the students become more skillful in using e-learning. The pandemic has necessitated the use of e-learning to keep teaching-learning activities going. After more than a year of pandemics, students are most likely to have honed the skills needed to use and operate e-learning for teaching and learning. Students have become accustomed to e-learning and understand how to use it effectively.

"Besides that, I can also explore and improve soft skills, especially in the field of technology" (LD, personal communication, 2021)

It can be concluded that even during this pandemic there are still opportunities that arise and can be used as a chance to enrich oneself with knowledge and skills. Subsequently, they are already familiar with various kinds of e-learning systems, how to use them, and also practice them directly.

\section{Positive Projection of Future Practices}

The students' experiences serve as a reference point for future decisions. The table below shows that EFL students intended to use e-learning for studying; they get access to the e-learning that is used during COVID-19 so they keep using it for their future carrier.

\section{Table 8}

Positive Projection

\begin{tabular}{lcc}
\hline Positive Projection & Respondent & Percentage \\
\hline Intention to use & 44 & $50 \%$ \\
Accessibility & 48 & $54.5 \%$ \\
Future use & 33 & $37.9 \%$ \\
\hline
\end{tabular}


Mostly, the EFL students project their practice of using e-learning in the future, which is supported by the result of the interview with EFL students. Although there are barriers, students want to use it as a tool of teaching later in their careers when they become teachers.

"If I become a teacher later, I want to create a classroom atmosphere that is not only lecturing in front of the class but must be accompanied by the optimal use of technology for the ease of student learning" (AAR, personal communication, 2021)

Students who have seen the advantages of using e-learning tend to merge face-to-face learning with the use of e-learning. They want to foster a more productive learning environment by integrating face-to-face and e-learning.

"Most of the platforms used are easily accessible on both laptops and smartphones, making the learning process easier" (FI, personal communication, 2021)

Furthermore, the ease of access to e-learning is the reason students continue to use it. They can access e-learning from their laptops and smartphones, as almost all students own these devices. Students expect that elearning will be beneficial in the future. Learning can be done anywhere and at any time, making it more versatile.

\section{CONCLUSION}

To conclude the study, EFL students accept the use of e-learning during the COVID-19 pandemic. Acceptance of e-learning is shown by projecting themselves to continue adopting e-learning in the future. EFL students also state that they will continue to use e-learning technology for teaching when they become teachers. The experience of EFL students using e-learning while studying at educational institutions has developed the notion that e-learning should be used when teaching. As the result, they gain confidence in implementing e-learning in the classroom.

During COVID-19, some challenges and opportunities are perceived by EFL students in the usage of e-learning. The difficulties encountered by them can be used as a model by lecturers and campus administrators to improve distance learning. While EFL students can use the opportunities they have had 
to develop their abilities and add skill, particularly in the field of e-learning. Because of the challenges that students face, it is critical to develop lesson plans and modules that can be adapted to distance learning. As a result, research and development of lesson plans and modules to accommodate various contexts of e-learning are required. Teachers must also engage in training. To optimize the effectiveness of e-learning, teachers are taught to teach remotely using elearning. Training also helps teachers adjust to difficulties that arise in the online classroom later on.

Thus, the study provides useful insight but is limited by the number of available participants. Other research is expected to cover a wide range of participants and address the acceptance of e-learning from the standpoint of EFL teachers in Indonesian higher education so that the specific benefits and constraints, as well as solutions for online learning implementation, can be identified.[rgt]

\section{REFERENCES}

Technology Acceptance Model for E-Learning (GETAMEL) by analysing commonly used external factors. Computers in Human Behavior, 56, 238256. https://doi.org/10.1016/j.chb.2015.11.036

Almekhlafy, S. S. A. (2020). Online learning of English language courses via blackboard at Saudi universities in the era of COVID-19: perception and use, Online learning of English language. 17. https://doi.org/10.1108/PRR-0820210-0026

Ashrafi, A., Zareravasan, A., Rabiee Savoji, S., \& Amani, M. (2020). Exploring factors influencing students' continuance intention to use the learning management system (LMS): A multi-perspective framework. Interactive Learning Environments, 1-23. https://doi.org/10.1080/10494820.2020.1734028

Bandura, A. (1982). "Self-Efficacy Mechanism in Human Agency", American Psychologist, vol. 37, no. 2, p. 26.

Chopra, G., Madan, P., Jaisingh, P., \& Bhaskar, P. (2019). Effectiveness of e-learning portal from students' perspective: A structural equation model (SEM) approach, Interactive Technology, and Smart Education. 24. https://doi.org/10.1108/ITSE-05-2018-0027 
Chung, H.-H., Chen, S.-C., \& Kuo, M.-H. (2015). A Study of EFL College Students' Acceptance of Mobile Learning. Procedia - Social and Behavioral Sciences, 176, 333-339. https://doi.org/10.1016/j.sbspro.2015.01.479

Davis, F. D. (1989). Perceived Usefulness, Perceived Ease of Use, and User Acceptance of Information Technology. MIS Quarterly, 13(3), 319. https://doi.org/10.2307/249008

Dhawan, S. (2020). Online Learning: A Panacea in the Time of COVID-19 Crisis. Journal of Educational Technology Systems, https://doi.org/10.1177/0047239520934018

Edgar, T. W., \& Manz, D. O. (2017). Research methods for cybersecurity. Syngress, an imprint of Elsevier.

El Refae, G. A., Kaba, A., \& Eletter, S. (2021). Distance learning during COVID-19 pandemic: Satisfaction, opportunities, and challenges as perceived by faculty members and students. Interactive Technology and Smart Education, aheadof-print(ahead-of-print). https://doi.org/10.1108/ITSE-08-2020-0128

Fincham, D. (2016). Implications and Challenges in Studying as a Full Distance Learner on a Masters Programme: Students' Perspectives. International Journal of Higher Education, 6(1), 34. https://doi.org/10.5430/ijhe.v6n1p34

Grubic, N., Badovinac, S., \& Johri, A. M. (2020). Student mental health in the midst of the COVID-19 pandemic: A call for further research and immediate solutions. International Journal of Social Psychiatry, 66(5), 517-518. https://doi.org/10.1177/0020764020925108

Ismaili, Y. (2021). Evaluation of students' attitude toward distance learning during the pandemic (Covid-19): A case study of ELTE University. On the Horizon, ahead-of-print(ahead-of-print). https://doi.org/10.1108/OTH-09-20200032

Joshi, O., Chapagain, B., Kharel, G., Poudyal, N. C., Murray, B. D., \& Mehmood, S. R. (2020). Benefits and challenges of online instruction in agriculture and natural resource education. Interactive Learning Environments, 1-12. https://doi.org/10.1080/10494820.2020.1725896

Kratochvil, J. (2014). The efficiency of e-learning in an information literacy course for medical students at Masaryk University. The Electronic Library, 32(3), 322-340. https://doi.org/10.1108/EL-07-2012-0087

Kumar Basak, S., Wotto, M., \& Bélanger, P. (2018). E-learning, M-learning, and Dlearning: Conceptual definition and comparative analysis. E-Learning and Digital Media, 15(4), 191-216. https://doi.org/10.1177/2042753018785180 
Luaran, J. @ E., Samsuri, N. N., Nadzri, F. A., \& Rom, K. B. M. (2014). A Study on the Student's Perspective on the Effectiveness of Using e-learning. Procedia Social and Behavioral Sciences, 123, 139-144. https://doi.org/10.1016/j.sbspro.2014.01.1407

Mendikbud. (2020). Surat Edaran Mendikbud: Pembelajaran secara Daring dan Bekerja dari Rumah dalam Rangka Pencegahan Penyebaran Corona Virus Disease http://kemdikbud.go.id/main/files/download/c5d9f0ec9ff40c6

(COVID-19).

Miles, M. B., Huberman, A. M., \& Saldaña, J. (2014). Qualitative data analysis: A methods sourcebook (Third edition). SAGE Publications, Inc.

Mishra, L., Gupta, T., \& Shree, A. (2020). Online teaching-learning in higher education during lockdown period of COVID-19 pandemic. International Journal of Educational Research Open, 1, 100012. https://doi.org/10.1016/j.ijedro.2020.100012

Moreno, V., Cavazotte, F., \& Alves, I. (2017). Explaining university students' effective use of e-learning platforms: Effective use of e-learning platforms. British Journal of Educational Technology, 48(4), 995-1009. https://doi.org/10.1111/bjet.12469

Rizun, M., \& Strzelecki, A. (2020). Students' Acceptance of the COVID-19 Impact on Shifting Higher Education to Distance Learning in Poland. International Journal of Environmental Research and Public Health, 17(18), 6468. https://doi.org/10.3390/ijerph17186468

Ryan, R. M., \& Deci, E. L. (2000). Intrinsic and Extrinsic Motivations: Classic Definitions and New Directions. Contemporary Educational Psychology, 25(1), 54-67. https://doi.org/10.1006/ceps.1999.1020

Sarker, F. H., Mahmud, R. A., Islam, M. S., \& Islam, K. (2019). Use of e-learning at higher educational institutions in Bangladesh: Opportunities and Challenges, Journal of Applied Research in Higher Education, https://doi.org/10.1108/JARHE-06-2018-0099

Schworm, S., \& Gruber, H. (2012). e-Learning in universities: Supporting helpseeking processes by instructional prompts: Supporting help-seeking in elearning environments. British Journal of Educational Technology, 43(2), 272-281. https://doi.org/10.1111/j.1467-8535.2011.01176.x

Shah, D. (2016). Online education: Should we take it seriously? Climacteric, 19(1), 3-6. https://doi.org/10.3109/13697137.2015.1115314 
Smith, B., Caputi, P., Crittenden, N., Jayasuriya, R., \& Rawstorne, P. (1999). A review of the construct of computer experience. Computers in Human Behavior, 15(2), 227-242. https://doi.org/10.1016/S0747-5632(99)00020-5

Venkatesh, Morris, Davis, \& Davis. (2003). User Acceptance of Information Technology: Toward a Unified View. MIS Quarterly, 27(3), 425. https://doi.org/10.2307/30036540

Yeou, M. (2016). An Investigation of Students' Acceptance of Moodle in a Blended Learning Setting Using Technology Acceptance Model. Journal of Educational Technology Systems, 44(3), 300-318. https://doi.org/10.1177/0047239515618464

Yin, R. K. (2018). Case study research and applications: Design and methods (Sixth edition). SAGE. 
This page has been intentionally left blank. 